https://doi.org/10.7592/Sator.2017.18.07

146

\title{
The Saints of Death in the Traditions of the Balkan People
}

\author{
Rachko Popov
}

\begin{abstract}
Balkan Ethnology Department, Institute of Ethnology and Folklore Studies with Ethnographic Museum, Bulgarian Academy of Sciences rachko.popov@iefem.bas.bg
\end{abstract}

\begin{abstract}
The article examines various versions of the myth of the division of the world among the saints in the South-Balkan folklore. Notwithstanding the diversity in the recorded versions of this myth, the functions of a master of death and of the nether world of souls are attributed to Archangel Michael; the Islamic peoples and communities on the Balkans assign the functions of an angel of death to Israel/Azrael. Many Christian saints have got the power to punish human beings by depriving them of their lives. Usually, in such cases the motif of a committed sin is involved, most often in relation to non-observance of a particular kind of taboo.
\end{abstract}

Key words: Balkan, folklore, master of death, saint, Balkan

In Bulgarian folk songs and tales there is a very popular theme relating the story of the division of the world among the saints. When God created the world and the first people on earth, he convoked a meeting of all the saints. St. Elijah was ordered to reign over heaven and over the summertime heavenly elements. St. Nicholas was granted supremacy over the oceans, seas and rivers. Archangel Michael was appointed to be the ruler of death and of the nether kingdom of the dead. In a folk song from the region of Tsaribrod, this cosmogonical myth is presented in a particularly expressive manner: when the three main cosmic realms: the heaven, the earth and the nether kingdom of the dead, were divided among the three "brothers" St. Elijah, St. Nicholas and Archangel Michael, "the sky thundered, the earth quaked and fish in the seas started fighting". However, in various versions of this myth in the folklore of the Bulgarians other saints are also involved in sharing the global spheres of influence: St. Athanasius assumes command over the winter while St. Paul over the summer; St. John assumes patronage over sponsorship and fraternization, while St. Peter takes charge of the paradise (Yankova 2000). Notwithstanding the diversity in 
the recorded versions of this myth, the functions of a master of death and of the nether world of souls are always attributed to Archangel Michael. That is why within the entire ethnic territory of the Bulgarians he is known by the nickname vadidushnik or dushevadnik ('soul taker').

In the popular conceptions and the folklore of Bulgarians, Archangel Michael is described as the most impartial among saints since "he forgives no one, neither the poor, nor the rich; neither men, nor women." When a man's hour of death comes, the saint "flies in through the chimney of the house" and stands at his deathbed with a golden apple in hand to lure his soul out and facilitate its parting with the body. As a folk song from the region of Plovdiv has it, God presented the Archangel with the golden apple so that he could easily entice the soul of the ailing Yana, which he did not dare take for nine long years. Archangel Michael takes the souls of dying sinners by stabbing them with a knife or sword. This is why burial tradition requires that a clean towel and a bowl of water be placed at the deathbed of every person so Archangel Michael can wash and wipe his hands after having wrung the soul out of the body of the sinful deceased.

A number of folklore motifs depict Archangel Michael as a "deaf and blind old man". God deprived him of his hearing and eyesight, and put a sharp scythe (sword, knife) in his hands because once, when he was sent to take the soul of a poor widow who had infant children, he took pity on her and spared her life. According to the beliefs of the Greek-speaking Karakachans (nomad mountain shepherds) as well, Archangel Michael is deaf. God deprived him of hearing because the saint was too merciful. Thus he would not be able to hear the whining and laments of parents whenever he has to take the souls of their children (Pimpireva 1998: 96).

After taking the soul of a deceased person Archangel Michael leads it along the path to the place of judgment in heaven where it should give an account of all its earthly acts and deeds before God and St. Peter. This is why in iconography he is often depicted with a pair of scales (symbol of justice) in his hands, with the help of these he weighs out the goodness done and the sins committed by the deceased (Kretzenbacher 1958). 
It is an interesting fact that Archangel Michael is honoured by Bulgarians also as a heavenly patron of butchers since they likewise take the souls of slaughtered animals with their knives. Among Greeks the archangels Michael and Gabriel are also venerated as patrons of artisan butchers (Varvunis 2001: 183).

Among the rest of South Slavic peoples of the Balkans, belonging to the Eastern Orthodoxy and to Catholicism, Archangel Michael is in addition known by the nicknames dushovadnik, vadidushnik or kruvnik ('sole taker' or 'the bloodthirsty') (Kuret 1970: 13-16; Bandić 1991: 21; Vražinovski 2000: 359), though among Serbs and Croats his functions of interceding with God for the souls of the dead are largely attributed to St. Nicholas. We need to clarify here that according to the official Orthodox calendar of Bulgarians, Serbs, Montenegrins, Greeks, Romanians and Albanians, the feast day of Archangel Michael is celebrated on October 8th, while Catholic Croats, Slovenes and Albanians celebrate it on September 29th, referring to it respectively as Mihovil or Mohoya (Croats), Mihelovo (Slovenes), Shen Mili (Albanians). Various legends depict the Archangel as a deity of the underworld, leading the souls of dead men to the other world; as a young man having 12 wings with which he screens and protects the moon from the raids of the lamia; as a God's messenger appearing either as a wanderer or as a beggar to entice the soul of the dying man with a sprig of basil (if he is righteous) or pierce it with a lance (if he is sinful). He holds a pair of scales in his hands to weigh the sins of the dead. He sends righteous souls to the guardian of the gates of Paradise, St. Peter, showing them the way with his right hand. With his left hand he sends off the sinful directly to hell (Bandić 1991: 21-24; Petrović 2000, T. 5: 313).

In the entire Balkan area the feast day of Archangel Michael is regarded as a "hard, cumbersome holiday". On the Saturday right before the feast day all Orthodox Christians commemorate one of the major official annual All Souls' days named after the Archangel. Serbs often also call it "closed" (Nedeljković 1990: 99; CMP: 188) or "autumn All Souls' day". Women make special oval or cruciform ritual loaves of bread which they give away together with boiled wheat to other people as offering at the cemetery. Quite often such loaves of bread are named after the Archangel or St. Petka (Bosić 1996: 185; Pamfile 1997: 207). Among South Slavic peoples the feast 
day of the Archangel is also particularly preferred for organizing family reunions and community celebrations accompanied by a blood sacrificial offering and well laden common festive tables known as sluzhba, svetets, slava ('service', 'saint', 'glory'). In Eastern Herzegovina, at such family feasts, the host addresses the Archangel with the words: "May God permit St. Michael the Archangel to protect us from any misfortunes and hardships of life with his wing and with his flaming sword!" (Šarenac 1986: 245-246).

According to Greek traditional folk beliefs, the Archangels Michael and Gabriel were not trusted by God with the task to lead away the souls of dead persons to the kingdom of heaven. They have got thick ledgers wherein they record the names of their victims, particularly those who do not pay homage to their feast day. The population in the region of Ainos has the custom of hiding their shoes on the eve of calendar feast days, which otherwise are left outside in front of their doors. They believe that by doing this they will avoid premature death. Tradition requires that in honour of Archangel Michael the eldest men in a family should slaughter a rooster in close proximity to the temple or chapel of the saint with burning candles arranged around the sacrificial fowl (Megas 1963: 20-21; Constantinidou-Partheniadou 1992: 350). Bulgarians from the lands of Thrace also slaughter roosters on the feast day of the Archangel (Vaseva 2002: 9).

Many of the scientists doing research work on religions perceive the image of the Christian Archangel as a kind of successor to the ancient ferryman Charon who carries the souls of the newly deceased across the river of oblivion. Greeks often call him Charos (Lawson 1964: 45; Rodd 1968: 114-117). In their ancient conceptions the god of the dead is an enormous man with flashing eyes riding a black horse and wielding a sharp sword in his hand. He also carries arrows which he aims directly at the heart of his victim. Sometimes he is depicted as a vinedresser, a mower or harvester equipped with the appropriate cutting implement (pruning knife, scythe, sickle). Quite often he has some animal features - he is winged, his nose is like a bird's beak, his ears are long, his teeth are like the fangs of a predator. He turns into an eagle, snake or swallow. He is the keeper of the "lamps of human life". As soon as the oil in them burns out, the person dies. ${ }^{1}$ And when God decides 
to get married (this motif of His marriage is particularly widespread in the Greek folklore), ${ }^{2}$ mass death sets in among people. This is because for His wedding banquet, instead of lambs, He "butchered infants" (Schmidt 1871: 224-236; Kyriakidis 1968: 102). The mythological relation Charon-Archangel Michael is also present in the conceptions of Romanian speaking nomadic Aromanians or Armâns (nicknamed Cincars / Tsintsars, Koutsovlachs). Among them the saint is known by the sobriquet Khar. In a similar context we should also include the folk curses popular in south Bulgarian lands wherein the demonic personage of kharo is always present as a kind of personification of death: "May Kharo eat you!", "May Kharo take you!" (Dukova 1992). In some places in the lands of Thrace, death has its Christian mistress embodied in St. Anastasia (December 22nd). In the Rhodope region the saint is called Nastasha or St. Black. On her feast day women do no work at all for fear of having "their house blackened" (to avoid death in their household). An interesting fact to mention here is that, mainly in south Bulgarian lands, there is another Christianized androgynous personage of the same name - St. Chernyo/Timnyo ('Blackie'/Darkie') or Baba/St. Cherna ('Granny'/'St. Black'). Calendar celebration thereof occurs twice per year - in the winter and in the summer - and always follows the wintertime and summertime feast days in honour of St. Athanasius. In the region of the Sakar Mountain the function of a saint assisting dying people is entrusted to the "brother" of St. Athanasius, St. Antonius, called "St. Andonius the Saviour" in this region. When a man starts having severe deathbed pains the tradition requires that an icon of St. Andonius be placed beside him so that it would be easier for the soul to part with the body (Popov 2002: 314). Analogous concepts are also found among the population of Macedonia. When someone falls ill and is bedridden for a long period of time, an icon of St. Andonius is placed beside him on the bedclothes: "If his time to die has come, may St. Andonius take his soul, if he is going to recover, then the saint will bring him health sooner" (Risteski 2001: 166).

It seems to me that in the south Bulgarian lands the mythologyrite relation of the triad of saints Antonius-Athanasius-Euthymius/ Blackie (January 17th, 18th, 20th) with Death has been influenced by the traditional outlook of the Greeks on life. The folk etymology of

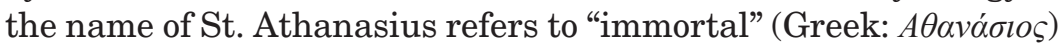




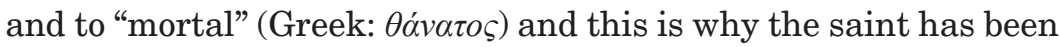
proclaimed patron saint of a large number of graveyard churches in Greece. Among Greeks there is a widely used phrase: "He now belongs to St. Athanasius" when referring to a man on his deathbed. To render homage to the saint of death, families used to slaughter roosters in his honour. The fowl is dedicated to the health of the entire family. Among Bulgarians the sacrificial offering of a rooster or a black hen is typical of the feast day of St. Euthymius who often duplicates on an etymological and ritual level the character of Timnyo or Chernyo. It seems that the semantic relation between St. Athanasius and his supremacy over death exerts decisive influence on the formation of an overall impression from the symbolic meaning of the holy triad. According to D. Lukatos, in the triad we can perceive a somewhat modern flavour of the ancient concepts about the three goddesses of destiny - the Greek Moirai (the Fates), who spin the thread of life of each new-born child on the first or the third night after its birth:

Saint Antonius was writing, Saint Athanasius was cutting, And Saint Euthymius was censing... (Loukatos 1985: 91-96)

Yet another explanation is also plausible with regard to the relation between St. Athanasius and St. Black on the one hand and death on the other. Again, it is based on etymology. In the Orthodox calendar of Bulgarians and Greeks the summertime feast day of St. Athanasius (May 2nd) is followed by the feast day of the martyrs St. Timothy (correlation with the words tama, tamen 'dark', 'darkness') and St. Mavra (translation from Greek 'black'). On the feast day of St. Mavra (May 3rd) Greek women abstain from using knives and scissors and avoid sewing garments because of the belief that their hands would be stained black. Elderly women are necessarily dressed in black on that day. No domestic and business initiatives are undertaken since these are all bound to be unsuccessful. Ethnographic sources indicate that when epidemics of infectious diseases broke out during the Ottoman rule, the churches and chapels named after St. Mavra became the most frequented holy places for the Greeks because of the sick seeking healing there (Megas 1963: 121; Constantinidou-Partheniadou 1992: 186). 
Another triad of saints is also related to the conceptions about death and the other world of the dead in the Orthodox tradition of the Balkan peoples. This is the calendar triad St. Barbara - St. Sava (Sabbas) - St. Nicholas (December 4th, 5th and 6th). Among the Greek-speaking nomad Karakachans on the Balkans there is a popular saying: "Saint Barbara sickens, Saint Sava covers with cerecloth and Saint Nicholas buries" (Пимпирева 1998: 96). Its Romanian version is analogous: "Barbara commits barbarity, Sava reads burial service and Nicholas entombs" (Pamfile 1997: 237). An interesting fact in this case is that Bulgarians, Romanians and Karakachans often associate the name of the second saint in this triad with the female gender referring to the saint as "Saintess Sava". Again, as a result of the folk etymology, the name is associated with the word savan ('cerecloth'), from there with the concept of death, as well. There is a belief among the Greeks that they must pay special homage to the saint and pray to him to salvage their souls in the realm of the dead. According to a legend of theirs, St. Sava holds a net with his hands over the river of fire flowing through hell. If he happens to be angry or displeased with someone, he can loosen his grip on the net and the sinful soul would drop into the river (Loukatos 1985: 29-30). On St. Sava's feast day a non-canonical All Souls' Day is observed by Bulgarians in the region of Plovdiv. Women necessarily give away cooked wheat berries as offering in commemoration of their departed relatives (Stamenova 1986: 245). To the Romanians in Muntenia, "Saint Sava" is a sacred woman, who once suffered from measles. As a consequence of this illness she was left blind in one eye. On her feast day each woman prepares three tapers of pure wax and consecrates them to the saint in front of her icon in the church. After the divine service they take these tapers home. Whenever someone is taken ill with measles or seems to go mad, the three tapers are lit.

As I have mentioned earlier, in the traditions of Serbs and Croats in Slavonia the functions of a delegate of the souls of the dead in the other world are entrusted to St. Nicholas, also called "the Traveller”. In this sense a folk song recorded by Vuk Karadžić is particularly indicative:

Please stay Saint Nicholas,

Let's go to the forest, 
Let's build ships,

And use them to carry the souls

From this world into the other. (Nodilo 1981: 531)

A number of researchers of the old Serbo-Croatian religion presume that the mythological involvement of St. Nicholas with domination over waters and shipping predetermines his function of a saint taking the souls of dying people (secondary function probably arising on the basis of this domination). Thus, he turns into a kind of substitute for Archangel Michael, the chief Eastern Orthodox master of the souls of the dead. In this sense some prominent representatives of the Serbian and Croatian ethnology descry a Christianized follower of the ancient Charon in the figure of St. Nicholas, while others relate him to Wodan, the Germanic god of the dead (Čajkanovic 1973: 333-334; Nodilo 1981: 531; CMP: 399; Petrović 2000, T. 5: 314).

In the mythology and the calendar tradition of the Slovenes the image of St. Varvara (St. Barbara) is loaded with the concepts of death and the other world of the dead. The vivid description of the throes of death of the saint in the hagiography served as a basis for emergence of a great number of folklore texts (songs, sagas and legends) which reiterate the motif of her heroic death. In a similar context various folk beliefs were born, some of which depict the saint as an unfailing attendant to people on their deathbed. Others characterize her as a keen and ardent patroness of the artisans who are under a daily threat of severe injury or death due to their working environment (miners, foundry workers, blacksmiths, masons, stone quarry workers). This is why Slovenes call St. Barbara "Attendant at death". On her feast day everybody carries a piece of iron (or a petty ferrous object) hidden in their clothes to protect themselves from demons, witchcraft, diseases, and death (Möderndorfer 1948: 27; Kuret 1970, T. IV: 13-14). In Catholic tradition, to a certain extent, analogous functions are attributed to St. Gertrude (March 17th). According to the words of the prominent German investigator of the cultural heritage of the peoples from South East Europe, L. Kretzenbacher, the saintess bears a close resemblance to the Orthodox Archangel Michael because on the first night after a man's death his soul is under the control of St. Gertrude (Kretzenbacher 1958: 112-116). The concepts of Romanians about St. Barbara are analogous to those of Slovenes. They also believe that the saint helps 
those dying; she alleviates their suffering and takes their souls less painfully (Pamfile 1997: 236). Anyhow, among all Orthodox peoples on the Balkans St. Barbara is venerated as the master of measles. According to Greek ethnologists, her image includes reflections of some ancient pagan beliefs and conceptions related to the reverence for the goddess Hecate, protector of children, city gates and roads, as well for the three goddesses of destiny, the Moirai (Megas 1963: 24-25; Loukatos 1985: 23-26).

While outlining the Balkan model of the saints, lords of death, I would like to add that the Islamic peoples and communities on the Balkans assign the functions of an "angel of death" to Israel/Azrael. In the conceptions of the Muslims, he is invisible to common people although he is of enormous stature, with multiple legs and multiple wings (Lozanova 1998: 21). Along with these saints "specialized" in taking human lives, in the tradition of the Balkan peoples there are many other beliefs and concepts of similar nature, too. Reference is made here to those Christian saints who have also got the power to punish human beings by depriving them of their lives. Usually, in such cases the motif of a committed sin is involved, most often in relation to non-observance of a particular kind of taboo. All saints are known to get angry when women and men work on the official calendar feast days. But apparently among the "angriest" in this respect are St. Theodore, St. Paraskeva, St. Elija, St. Peter and St. Procopius. He takes the lives of those girls and women who meet for a working-bee to spin wool and chat. According to a Romanian myth, the cruel saint cuts the abdomens of maidens open, pulls out their intestines and spreads them over the farmyard fences or hangs them on the tree branches (Marian 1994: 244-248). In Western Bulgaria, Eastern Serbia and in Macedonia, St. Paraskeva (St. Petka "Friday" as translated from Greek) often appears in the form of a snake before those housewives who do not observe the taboo on wool spinning on Fridays and punishes them, sometimes even by death (Popov 2008: 76). Bathing and swimming in the sea or rivers on the feast days in honour of St. Elija, St. Peter and St. Procopius is banned by the tradition since these rulers of summertime elements always claim a victim - someone is drowned. Further examples of a similar kind can be provided but most likely this is unnecessary. They would just supplement the general traditional point of view outlining the beginning and the end of each human life as a thread 
spun by the Fates or by their Christian successors, the saints, i.e. "the thread of life."

\section{Notes}

${ }^{1}$ According to a legend from the region of Botevgrad, "the stars were born from the marriage of the sun and then became icon lamps of Our Lord." As every human being has got a dedicated star in the heavens, 40 days before her/his death the oil in the respective icon lamp starts to diminish until "God finally blows it out".

${ }^{2}$ According to the conceptions of the Greeks from the Ionian Islands, as reflected in their folk songs, Charon's wife is called Charontissa. Their wedding ceremony took place at sundown. The wedding table was covered with a black linen cloth and the cutlery resembled cut-off male arms and infant heads (Rodd 1968: 118).

\section{References}

Bandić, Dušan 1991 = Бандић, Душан 1991. Народна религија срба у 100 појмова. Beograd: Nolit.

Bosić, Mila 1996 = Босић, Мила 1996. Годишни обичаји срба у Војводини. Нови Сад: Музеј Војводине.

Čajkanović, Veselin 1973 = Чајкановић, Веселин 1973. Мит и религија у срба. Београд: Просвета.

Dukova, Ute 1992 = Дукова, Уте 1992. Някои антични мотиви в обредите и фолклора на балканските народи. Българска етнология, 3, pp. 43-48.

Constantinidou-Partheniadou, Sofia 1992. A Trevelogue in Greece and a Folklore Calendar. Athens: Athine.

Kretzenbacher, Leopold 1958. Die Seelenwaage. Zur religiöser Idee von Jenseitsgericht auf der Schicksaalswaage in Hochreligion, Bildkunst und Volksaberklaube. Klagenfurt: Verlag des Landesmuseums für Kämten.

Kuret, Niko 1970. Praznično leto slovencev. Starosvetne šege in navade od pomladi do zime, IV. Celje: Mohorjeva družba.

Kyriakidis, Stilpon K. 1968. Two Studies in Modern Greek Folklore. Thessaloniki: Institute for Balkan Studies. 
Lawson, John Cuthbert 1964. Modern Greek Folklore and Ancient Greek Religion. A Study of Survivals. Cambrige: University Press.

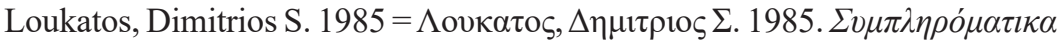

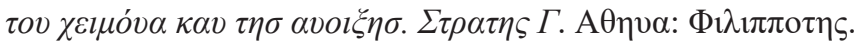

Lozanova, Galina 1998 = Лозанова, Галина 1998. Обичаи преди смъртта в контекста на южнославянския миторелигиозен синкретизъм. Българска етнологтия, 1-2, pp. 20-36.

Marian, Simion Florian 1994. Sărbatorile la Romăni, 1. ED. Bucureşti: "Grais Suflet. Cultura Natoinala".

Megas, Georgios A. 1963. Greek Calender Customs. Athens: s.a.

Möderndorfer, Vinko 1948. Verovanja, uvere in obiačji Slovencev, II. Celje: Družba Sv. Mohorja.

Nedeljković, Mile 1990 = Недељковић, Миле 1990. Годишни обичаји у срба. Београд: Вук Караџић.

Nodilo, Natko 1981. Stara vjera srba i hrvata. Split: Logos, Ljubljana.

Pamfile, Tudor 1997. Sărbătorile la romăni. Studii etnografic. ED SAECULUM IO.

Petrović, Sreten $2000=$ Петровић, Сретен 2000. Српска митологија, I-V. Београд: ПРОСВЕТА-НИШ.

Pimpireva, Zhenia 1998 = Пимпирева, Женя 1998. Каракачаните в България. София: IMIR.

Popov, Rachko 2002 = Попов, Рачко 2002. Обичаи и обреди при смърт и погребение. Сакар. Етнографско, фолклорно и езиково изследване. София: Акад. Изд. “Проф. М. Дринов”, pp. 313-323.

Popov, Rachko 2008 = Попов, Рачко 2008. Светции и демони на Балканите. Пловдив: “Летера”.

Risteski, Ljupcho 2001 = Ристески, Љупчо 2001. Поајм и место светайа у македонској народној религии. Култ светих на Балкану. Крагујевац: ПРОСВЕТА-НИШ, pp. 149-174.

Rodd, Rennell 1968. The Customs and Lore of Modern Greece. Chicago: Argonaut. 
Stamenova, Živka 1986 = Стаменова, Живка 1986. Календарни празници и обичаи. Пловдивски край. София: БАН, pp. 244-283.

Šarenac, Jovan 1986 = Шаренац, Јован 1986. Грађа о обичајима у Источној Херцеговини. Гласник етнографског музеја, 50, pp. 241-263.

Schmidt, Bernhard 1871. Das Volksglauben der Neugriechen und das Hellenische Altertum. Leipzig: B.G. Teubner.

SMR 1998 = Српски митолошки речник. 2nd ed. Београд,: ИНТЕРПРИНТ.

Varvunis, Manolis 2001 = Варвунис, Манолис 2001. Култ светих у гречкој традицијској култури. Култ светих на Балкану. Лицеум 5. Крагујевац, pp. $175-190$.

Vražinovski, Tanas 2000 = Вражиновски, Танас 2000. Речник на народната митологија на македонците. Прилеп-Скопије: "Матица Македонска".

Vaseva, Valentina 2002 = Васева, Валентина 2002. Задушницата в системата на българските обичаи. Българска етнология, 1, pp. 5-40.

Yankova, Veneta 2000 = Янкова, Венета 2000. Мотивьт "Делба на светци”. Етнографски проблеми на народната култура, VI. София: “Лотос”, pp. 9-33. 


\section{ELM Scholarly Press \\ SATOR 18}

http://dx.doi.org/10.7592/Sator.2017.18

\section{BALKAN AND BALTiCUM}

Current Studies in the Postsocialist Space

Edited by

Ekaterina Anastasova and Mare Kõiva

Tartu 2017 
Editors and compilers: Ekaterina Anastasova, Mare Kõiva Series "Sator" editor: Mare Kõiva

Language editors: Liisa Vesik, Lii Liin

Cover photo: Jaak Kikas, 2017 "Autumn in Tartu"

International committee

Tiiu Jaago (Tartu University); Reet Hiiemäe (Estonian Literary Museum); Mare Kalda (Estonian Literary Museum); Tarmo Kulmar (Tartu University); Nikolay Kuznetsov (Estonian Literary Museum); Aado Lintrop (Estonian Literary Museum); Emily Lyle (School of Scottish Studies in Edinburgh); Mirjam Mencej (Ljubljana University); Jonathan Roper (Tartu University); Marju Kõivupuu (Tallinn University); Ülo Valk (Tartu University); Tatjana Vladõkina (Institute of Udmurtian History, Language and Literarture, Izhkar); Irina Vinokurova (Institute of Karelian History, Language and Literarture in Petroskoi); Ergo-Hart Västrik (Tartu University)

Supported by Estonian Academy of Sciences, Bulgarian Academy of Sciences, the Centre of Excellence in Estonian Studies (CEES, European Regional Development Fund) and is related to research projects IRG 22-5 (Estonian Research Council).

\section{$\boldsymbol{C} E \mathbf{E} \times \begin{aligned} & \text { Centre of excellence } \\ & \text { in Estonian Studies }\end{aligned}$}

Series "Sator. Artikleid usundi- ja kombeloost", 18 http://www.folklore.ee/rl/pubte/ee/sator/sator18/

ISSN 1736-0323 (online)

ISBN 978-9949-586-58-5 (printed)

ISBN 978-9949-586-61-5 (online) ISSN 1406-2011 (printed)

DOI: 10.7592/Sator.2017.18

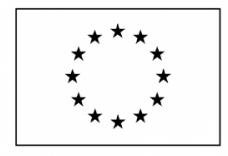

European Union European Regional Development Fund

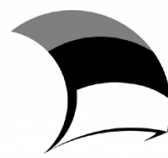

Investing in your future

\section{EUROPEAN UNION}

Regional Development Fund

Investing in your future
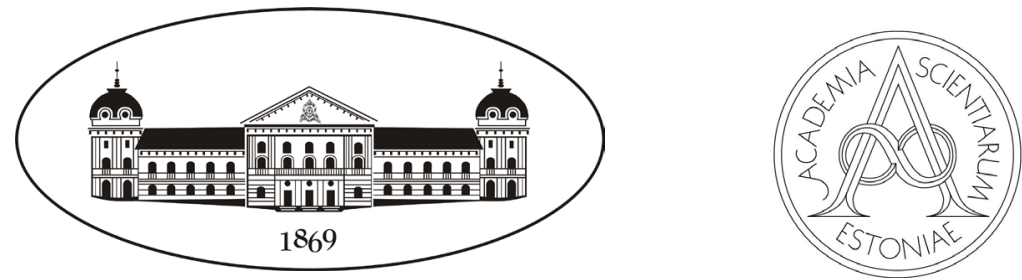


\section{Contents}

Preface

Mare Kõiva, Ekaterina Anastasova

CONSTRUCTING IDENTITY AND SOCIAL TIES

Ethnographic Studies on the Montenegrin

Festive Costume as a National Symbol

Sofiya Zahova

Social Ties of Bulgarians and Rudari in the Mediterranean Countries

Magdalena Slavkova

\section{RECASTING RELIGION AND \\ RELIGIOUS IDENTITY}

Contemporary Development of the Akyazili

Baba Tekke / St. Athanasius in Bulgaria

Yelis Erolova

Turkish Religious Identity in Bulgaria

94

in the Last Twenty-Four Years (1989-2013)

Mila Maeva

The Feast of Cyril and Methodius in Bessarabia and Crimea, Ukraine

Ekaterina Anastasova 
The Saints of Death in the Traditions

of the Balkan People

Rachko Popov

\section{CONSTRUCTING NEW SPIRITUALITY}

New Trends in the Study of Religion in Estonia -

Contemplations in the Grey Zone between

Religion and Science

Tõnno Jonuks

Constructing New Spirituality in Modernity -

the Case of the White Brotherhood in Bulgaria

Svetoslava Toncheva

Constructing Contemporary Periodical and

Occasional Rituals

Mare Kõiva

The Making of a Sacred Place:

221

An Example of Constructing Place Identity in the Contemporary Mentality

Reet Hiiemäe

\section{CHANGING TRADITIONS}

Bridge Over the Rainbow. Animal Burials and

Animal Cemeteries in Post-Socialist Estonia

Marju Kõivupuu

Simple Hide-and-seek at its Core: Play Features and the Game of Geocaching

Mare Kalda 